Journal Home Page:

http://perlinguam.journals.ac.za

\section{Per \\ Linguam}

A Journal for Language Learning Tydskrif vir Taalaanleer

\title{
GHANA LANGUAGE-IN-EDUCATION POLICY: THE SURVIVAL OF TWO SOUTH GUAN MINORITY DIALECTS
}

\author{
Mercy Akrofi Ansah \\ University of Ghana \\ Nana Ama Agyeman \\ University of Ghana
}

The paper investigates the survival of two South-Guan minority dialects, Leteh and Efutu, in the context of the Ghana language-in-education policy. The study is done from the perspective of the UNESCO Universal Declaration on Linguistic Rights (1996). In every multilingual state, the formulation of policies concerning language use has always presented challenges. The government has to decide which of the languages need to be promoted and for what purposes. In Ghana, since the introduction of formal education, English has indubitably been the language of education, trade, law, media, government and administration. However, there has always been a debate surrounding the language-in-education policy, especially at the basic level of education. The argument has always been whether English should be emphasised or Ghanaian languages. For purposes of formal education, the government of Ghana has promoted nine languages known as governmentsponsored languages. These are languages which have literary tradition and can be used as media of instruction in schools. This decision was to the detriment of some Ghanaian languages; languages which are often described as minority languages, and which are not governmentsponsored. The paper argues that, if language and culture are intertwined, and the culture of a people must be preserved, then language policymakers need to consider the linguistic rights of speakers of the so-called minority languages. Data for the study were sourced from language surveys and observation.

\section{Keywords}

Language policy, Ghana, South-Gua, vitality, Leteh, Efutu

\section{INTRODUCTION}

This paper discusses the fate of two minority dialects, Leteh and Efutu, in the context of Ghana's language-in-education policy. The study is done within the framework of UNESCO's Universal Declaration on Linguistic Rights (UDLR) (1996). The controversy surrounding the appropriateness and application of the Ghanaian Education Language Policy has been centred on basic education, hence the need to shed light on its structure in the present section. 


\section{Structure of the basic education system in Ghana}

The Ghana Education Service (GES) has the responsibility of supervising and implementing approved national policies and programs relating to pre-tertiary education (private and public) in Ghana (GES Act 506 3(1), 1995). In Ghana, basic education is run by both the government and private entrepreneurs.

The duration of basic education in Ghana is 13 years, depending on whether the school is privately or government owned. In the case of the latter, the first level, nursery, is skipped, and so the entry age is 4 years at the kindergarten level, reducing the number of years spent in basic education to 11 years. Table 1 is an overview of the basic education system in Ghana.

\section{Table 1: Basic education system in Ghana}

\begin{tabular}{|l|l|l|}
\hline Level & Number of years & Recommended start age \\
\hline Nursery & 2 & 2 \\
\hline Kindergarten (KG1-KG2) & 2 & 4 \\
\hline Lower Primary (P1-P3) & 3 & 6 \\
\hline Upper Primary (P4-P6) & 3 & 9 \\
\hline $\begin{array}{l}\text { Junior High School } \\
\text { JHS (1-3) }\end{array}$ & 3 & 12 \\
\hline
\end{tabular}

The history of language-in-education policy in Ghana

Lewis, Gary and Fennig (2013) report that Ghana has about 68 indigenous languages from three language families: Gur, Mande, Kwa (Niger-Congo) (see Figure 1). The languages under discussion are marked 64 and 66. 


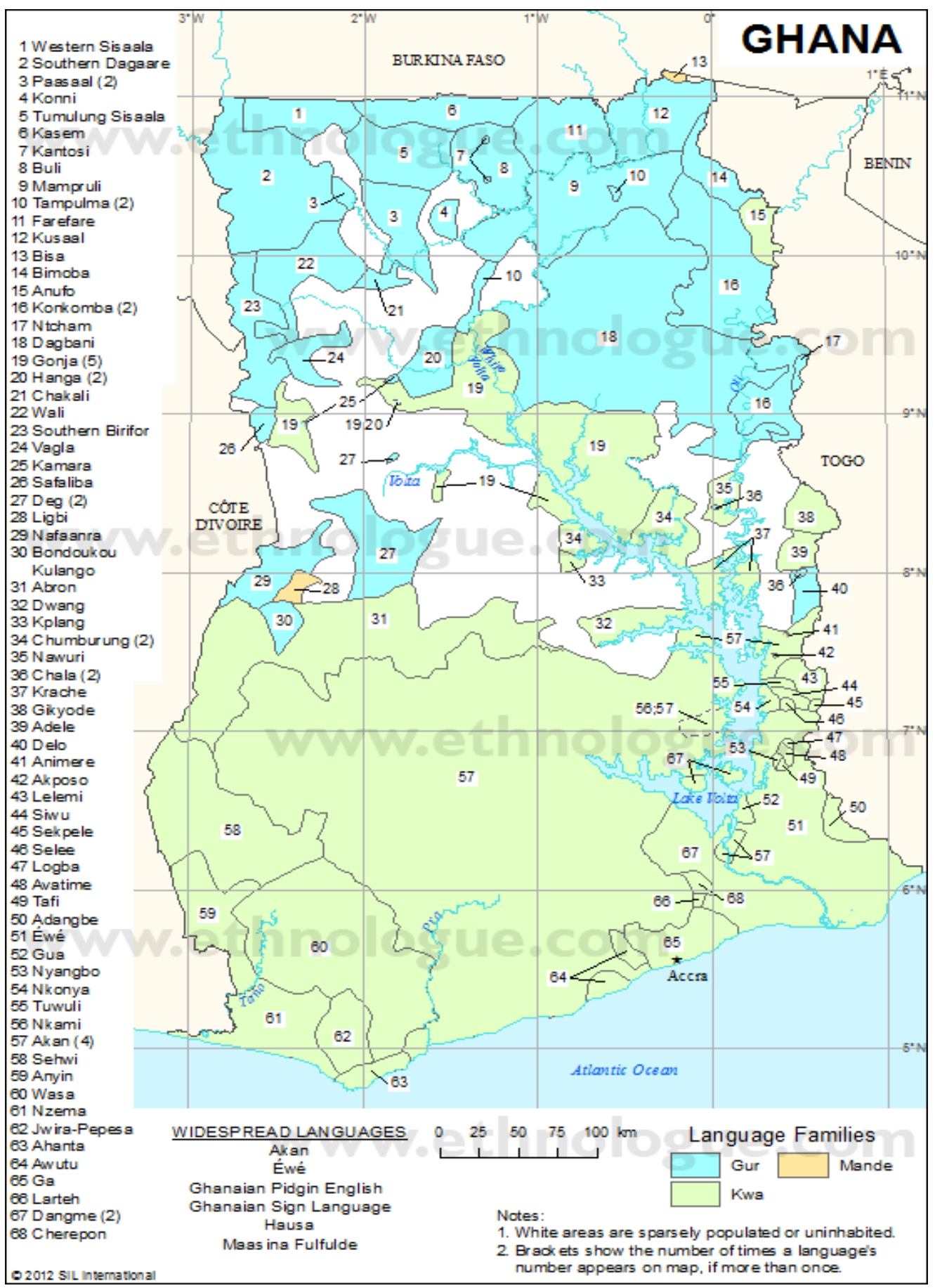

Figure 1: Language map of Ghana (Source: Lewis et al., 2013)

Akin to many multilingual societies, Ghana has faced the challenge of formulating an educational language policy which is efficacious and would ensure that standards of education are not compromised, and at the same time, that the culture of which language forms an integral part is also not sacrificed. This has led to the subjection of language-in-education policy to intense scrutiny 
over the years, often leading to its amendment, and confusion for both learners and teachers. Table 2 presents an overview of Ghana's educational language policy from 1529 to date.

Table 2: History of Ghana's language policy on education (Adapted from Owu-Ewie, 2006)

\begin{tabular}{|c|c|c|c|c|}
\hline PERIOD & YEAR 1 & YEAR 2 & YEAR 3 & $\begin{array}{l}\text { YEAR } 4 \\
\text { ONWARDS }\end{array}$ \\
\hline $1529-1925$ & & & & \\
\hline a. Castle schools era & - & - & - & - \\
\hline b. Missionary era & + & + & + & - \\
\hline $\begin{array}{l}\text { 1925-1951 (British } \\
\text { Colonial Rule) }\end{array}$ & + & + & + & - \\
\hline $\begin{array}{l}\text { 1951-1955 (British } \\
\text { Colonial Rule) }\end{array}$ & + & - & - & - \\
\hline $\begin{array}{l}\text { 1956-1966 (Independence } \\
\text { 1957) }\end{array}$ & - & - & - & - \\
\hline $1967-1969$ & + & - & - & - \\
\hline $1970-1973$ & + & + & + & + \\
\hline $1974-2002$ & + & + & + & - \\
\hline $2002-2007$ & - & - & - & - \\
\hline 2007-present & + & + & + & - \\
\hline
\end{tabular}

Key: (+) medium of instruction includes Ghanaian language

(-) medium of instruction excludes Ghanaian language

Table 2 depicts a flux in the emphasis on Ghanaian languages over the years. It is worth noting that, contrary to expectations, there was a complete disregard for Ghanaian languages when Ghana won independence in 1957. However, within 1970-1973, Ghana saw a complete shift from English as a medium of instruction to Ghanaian languages. The reform which attracted the biggest debate was that of 2002-2007, which encouraged the use of English as a medium of instruction at all levels. In the rest of the instances, we see a combination of Ghanaian languages and English as languages of instruction in basic education. In all of these scenarios, the point of departure has been what the language of instruction should be at the primary level: should it be English or a Ghanaian language?

Although the policy of a particular period emphasised the use of Ghanaian languages, it was actually selective in the sense that only the so-called nine government-sponsored languages were to be used. These are Akan (Akuapem, Asante, Fante dialects), Ewe, Ga, Dagbani, Dagaare, Dangme, Gonja, Kasem and Nzema. Adding to the confusion of which language must be used as language of instruction, were unclear statements in the policy. For example, in 1966, some clauses favoured pupils who studied in 'metropolitan and urban areas'; a 'late exit' was proposed for children who 
were more exposed to English language. In that case, the policy favoured pupils of a certain social status.

\section{The current policy: 2007-present}

The Government of Ghana launched a New Education Reform in response to what was described as a national literacy and numeracy crisis. This was to ensure that primary school pupils will be functionally literate and numerate, and will have reading fluency in the mother tongue (L1) and in English (L2) (Educational Strategic Plan 2003-2015). It had been reported that only $26 \%$ of pupils who reach the sixth and final year of primary school are literate in English and only $11 \%$ are numerate (2007 National Education Assessment). Under the New Education Reform, the Ministry of Education was tasked with the duty of developing a programme the National Literacy Acceleration Programme (NALAP) to address the poor educational standards. The National Literacy Task Force of Ghana's Ministry of Education, with support from United States Agency for International Development, crafted NALAP. NALAP postulates a bilingual approach to teaching so that pupils will first learn to read in their first language, and then the skills acquired will be transferred to read in English. NALAP aims to ensure that all children from kindergarten to Primary 3 have quality literary materials, effective instruction, and public support to learn to read and write in their mother tongue and English (NALAP Baseline Assessment). In Table 2, the implementation plan of NALAP is outlined.

\section{Table 2: Implementation plan of NALAP}

\begin{tabular}{|l|l|l|}
\hline Level & \% of Ghanaian Language (L1) & \% of English (L2) \\
\hline Kindergarten 1 and 2 & $90 \%$ & $10 \%$ \\
\hline Primary 1 & $80 \%$ & $20 \%$ \\
\hline Primary 2-3 & $50 \%$ & $50 \%$ \\
\hline Primary 4-Junior High School & $0 \%$ & $100 \%$ \\
\hline
\end{tabular}

The table shows the Ghanaian language and English ratios that NALAP recommends at the various stages of basic education. NALAP suggests that the majority of instructional time should be in a Ghanaian language (L1) at the initial stage, and be decreased gradually, while English is introduced and increased gradually until it finally replaces the L1 as instructional language by the beginning of upper primary (Primary 4). It must be noted that, here, Ghanaian language refers to one of the nine government-sponsored languages. We must not lose sight of the importance of one's L1 in one's education, especially at the basic level. Countless research demonstrates that knowledge of linguistic skills in L1 actually enhances the process of L2 learning (Andoh-Kumi, 1997; Bamgbose, 1991, 1997, 2000, 2005; Collinson, 1972; Fafunwa, 1989; Schwartz, Moin \& Leikin, 2012).

This paper argues that Ghana's language policy, principally that of education, is detrimental to the development of Ghanaian languages, particularly the so-called minority ones. The argument is buttressed by findings emanating from a myriad of studies which have been conducted on the role of mother tongue and minority languages in education (Bamgbose, 1991, 1997, 2011; Batibo, 1995 , 1997, 2004; Kaplan \& Baldauf, 1997; Kembo-Sure, 2000). The scholars bemoan the low esteem that minority languages are accorded in respect of domains of language use, and come out to support the use of minority languages in education. Batibo (1997), for instance, affirms that 
minority languages are important cognitive and affective instruments in education; they help minority language speakers to make sense of their world, and often help them to improve their mastery of the majority language. Among factors that contribute to the low status and restricted roles of minority languages are colonial legacy, negative perceptions of multilingualism, and defective language planning, which this study addresses (Bamgbose, 2011).

The remainder of the paper is structured as follows: in section 2, the sociolinguistic backgrounds of the two dialect communities are given. This is followed by a section which spells out the framework for the study, and also the methodology. In the two sections that follow (4 and 5), language use in the basic school classrooms in the two speech communities is described.

\section{THE SOCIOLINGUISTIC SITUATION IN THE TWO SOUTH GUAN COMMUNITIES}

This section reports on the sociolinguistic situation in the two dialect communities under study, Larteh and Winneba, where Leteh and Efutu are spoken respectively. The genetic affiliation of the two languages is displayed in Figure 2 (Lewis, 2009).

\section{Niger-Congo}

$$
\frac{\frac{\text { Atlantic-Congo }}{\text { Volta-Congo }}}{\frac{\text { Kwa }}{\frac{\text { Nyo }}{\underline{\text { Potou-Tano }}}}}
$$

Tano

\section{GUAN}

North Guan

\begin{tabular}{cc}
$\begin{array}{c}\text { Chumburung } \\
\text { Dompo }\end{array}$ & $\begin{array}{c}\text { (Ghana) } \\
\text { (Ghana) }\end{array}$ \\
Fwang & (Ghana) \\
Gikyode & (Benin) \\
Ginyanga & (Ghana) \\
Gonja & (Ghana) \\
Kplang & (Ghana) \\
Krache & (Ghana) \\
Nawuri & (Ghana) \\
Nchumbulu & (Ghana) \\
Nkonya & (Ghana) \\
SOUTH GUAN & \\
\hline Awutu & (Ghana) \\
Kyerepon & (Ghana) \\
Gua & (Ghana) \\
Ceteh (Larteh) & (Ghana)
\end{tabular}

Figure 2: Genetic affiliation of South Guan languages 
The sub-classification of the Niger-Congo phylum has been continuously modified (Williamson \& Blench, 2000). Figure 2, which represents the most recent classification by Lewis (2009) illustrates the genetic relationship that pertains among South Guan languages.

Lewis (2009) sub-classifies Guan into two language clusters, North Guan and South Guan. Members of the South Guan group are Awutu, Kyerepong, Gua and Leteh. Within the South Guan group, Gua and Cherepon are closer in terms of mutual intelligibility, and Leteh seems to be the most different (Kropp-Dakubu, 1988). Of the Guan dialects, only Gonja (North Guan) is government-sponsored.

\section{The socio-linguistic background of Larteh}

Leteh is spoken in only one town, called Larteh, in southeast Ghana. It is noteworthy that, in the literature and among non-speakers, both the dialect and the town are known as Larteh. In Larteh, multilingualism is the norm; all speakers are bilingual, with Leteh as the first dialect, and Akuapem Twi, an Akan dialect which also belongs to the Kwa group. In Larteh, therefore, Akuapem Twi is the lingua franca. The use of Akuapem Twi (Akan dialect) as a second language by Leteh speakers may be explained first and foremost by geographical factors, and secondly by the effects of educational policies on language. Larteh is isolated from other Guan-speaking groups and surrounded predominantly by Akuapem Twi-speaking towns. There is therefore a lot of social and commercial interaction between these two dialect groups. Secondly, the use of Akuapem Twi as the medium of instruction in the first three years of basic education in Larteh and surrounding towns puts the responsibility of learning Akuapem Twi on speakers of Leteh (Andoh-Kumi, 1999).

The educated ones speak English in addition, since it is the language of education, administration and trade in Ghana. There are also speakers who reside in the speech community, but are proficient in Dangbe (New Kwa language) due to trade relations with the latter group in the surrounding towns of Dodowa and Ayikuma.

Leteh is unwritten and does not possess an official orthography. The few existing texts in Leteh have therefore been written using the Akuapem Twi orthography, ${ }^{1}$ which is what the speakers are familiar with at school and church. Leteh is mostly used in the homes, among the speakers and also as a means of communication at traditional gatherings like funerals, festivals, marriage and child naming ceremonies. It is therefore considered as a domestic language only.

HN Riis, a Basel missionary who lived in Akropong, a neighboring town, from 1845-1849 described the linguistic situation in the following words:

In these towns, however, though in their families with their women and children they use their own idiom, yet the language of public intercourse is the Oji (Twi) which all grown up people understand and speak as well as their mother tongue (Riis, 1854: xii).

Leteh is therefore only used at home, while Twi (Akuapem Twi) is reserved for official settings. The linguistic situation may be summarised in the words of Brokensha (1966: xvii) as follows:

Three languages are in common use in Larteh; Gua (Leteh), Twi and English. Guan is generally the domestic language. At school, children learn English and they also have 
lessons in what is called 'vernacular', which is in fact Twi, for Guan is not taught at any school. Twi to some extent occupies the position of a prestige language.

\section{The socio-linguistic background of Efutu}

Lewis (2009) lists Efutu as one of three dialects of Awutu, with Senya and Awutu proper as the other two dialects, and classifies the Awutu language as follows: Niger-Congo>Kwa> Guang > Southern Guang> Awutu (see Figure 2). The immediate linguistic neighbours of the Awutu dialects are $\mathrm{Ga}$ and the Fante dialect of Akan.

Efutu is spoken in Winneba, a coastal town in the central region of Ghana with a population of about 68597 (Ghana Statistical Service, 2012). It is, however, uncertain that this number represents speakers of Efutu, due to the presence of immigrants in the language communities. Reports indicate that it is only a fraction, just about a third or less, of the population that actually speak Efutu (Agyemang 2013). Winneba, the Efutu-speaking community under discussion, is located in the south coast of Ghana, about 65 kilometres west of the capital, Accra. Other surrounding villages where Efutu is spoken include Osebonpanyin, Ekroful and Ateitu.

According to Boafo, Hatfield and Kehl (2002), the Efutu and Senya varieties are highly mutually intelligible with minimal differences in pronunciation, and they are distinguished mainly for political identification. The Awutu proper variety, however, is said to be less intelligible with the other two. Other ethnic groups found in the Awutu-Efutu-Senya include Ga, Dangme, Fante, Gomoa, Ewe and Hausa (Boafo et al., 2002).

The Efutu variety could be described as being threatened in the sense that, although Winneba is identified with Efutu, research has revealed that only a fraction of the population actually speaks the language. The dominant language in Winneba is the Fante dialect of Akan, which happens to be geographically adjacent to the Awutu-Efutu-Senya dialects, and is also spoken as a second language by the Awutu-Efutu-Senya community. Welmers (1973: 11) predicted the likelihood of Fante replacing Efutu. A more recent study by Abaka (2006) points out that it is possible to live in Winneba for a year or more without hearing anybody speak Efutu if one does not visit the fishing settlements.

Winneba has one university, three senior high schools and sixteen basic schools, twelve of which have a junior high school division. Religions practiced in the community include Christianity and traditional religion (Hagan, 2000). There are health facilities in the community, including a municipal hospital.

A common characteristic of the two communities under discussion is triglossia, a linguistic situation where three languages or language varieties are spoken in a community and each language has welldefined yet complementary functions in certain contexts (Eastman, 1983: 41). In Larteh, the two dialects and one language are in a triglossic relationship are Leteh (L1); Akuapem Twi, a local lingua franca; and English, the official language of Ghana. In Winneba and surrounding villages, it is Efutu (L1); Fante, the local lingua franca; and English. As already mentioned, in each case, the L1 is not used in school and public settings, and in the case of Efutu, its use is even prohibited in schools. 


\section{METHODOLOGY}

The study was conducted from the standpoint of the UDLR (1996). The essence of the UDLR (1996: 2) is '...to correct linguistic imbalances with a view to ensuring the respect and full development of all languages and establishing the principles for a just and equitable linguistic peace throughout the world as a key factor in the maintenance of harmonious social relations'.

Under Article 23 of the UDLR, the issue of education is addressed. In relation to the role of education in promoting minority languages, Article 23 (2) states that '[e]ducation must help to maintain and develop the language spoken by the language community of the territory where it is provided'. Furthermore, Article 29 (1) states that '[e]veryone is entitled to receive an education in the language specific to the territory where s/he resides'.

Relating the two provisions of the UDLR to the study, we maintain that speakers of Leteh and Efutu have the right to receive an education in their dialects, and the language-in-education policy of Ghana must favour the maintenance and development of these dialects.

An interdisciplinary method of data collection was used for the study: linguistic and anthropological. A linguistic survey of Larteh and Winneba was conducted to collect information on the linguistic repertoires of basic school pupils from three primary schools in Larteh and four primary schools in the coastal suburbs of Winneba. In total, 12 teachers were interviewed to ascertain their knowledge and implementation of the language policy on education in the classroom. Questionnaires to gather information on the linguistic background of school children were also administered. We sat through some lessons taught in the lower primary classrooms, and observed language use in the classroom. Further, we observed pupils during break-times to find out what languages they used when playing. Secondary sources that were consulted include policy documents on education (Ghana Education Reform, 2007; NALAP, 2009).

\section{FINDINGS}

From the interviews we had with the teachers, we gathered that they were aware of the bilingual model postulated by NALAP. However, we observed that they were unable to apply the policy to the letter. In some instances, some teachers who were required by the language policy to use particular languages were not proficient in those languages. Secondly, some of the teachers preferred to use English, obviously to impress the pupils. In all the schools, examinable languages were English and the L2, Akuapem Twi in Larteh and Fante in the case of Winneba. It is noteworthy that, for some of the learners, the first time they spoke the L2 was when they began attending school. This was the trend in both Larteh and Winneba.

In Winneba, the survey conducted showed that over $90 \%$ of the pupils spoke Efutu as their L1. Language of communication in the classroom was Fante and English, and Efutu was prohibited in school at all times, including playtime. This means that, outside the classroom, pupils continued to use Fante and English. In the case of Leteh, pupils were not forbidden to speak Leteh during playtime, and in fact, it was observed that a teacher who was proficient in Leteh spoke a word or two in Leteh when a Primary 1 child found it difficult to comprehend some terms in Akuapem Twi during a lesson in Environmental Science. Table 3 illustrates the linguistic background of the pupils in the three primary schools in Larteh. 
Table 3: Linguistic repertoire of pupils in Larteh

\begin{tabular}{|l|l|l|l|}
\hline School & $\begin{array}{l}\text { Presbyterian } \\
\text { Primary }\end{array}$ & Anglican Primary & $\begin{array}{l}\text { Methodist } \\
\text { Primary }\end{array}$ \\
\hline Number on roll & 40 & 38 & 17 \\
\hline English & 40 & 38 & 17 \\
\hline English, Akan & 40 & 38 & 17 \\
\hline English, Akan, Leteh & 38 & 35 & 14 \\
\hline
\end{tabular}

Table 3 indicates that all the pupils were bilingual in English and Akuapem Twi (Akan). The table further shows that a few of the pupils were not proficient in Leteh; the most likely reason being that they were migrants. For pupils who were bilingual in English and Akan, the latter was their mother tongue, and in the case of the trilingual pupils, their mother tongue was Leteh.

\section{Language use in the basic level classroom in Larteh}

The current Educational Language Policy of Ghana supports the use of mother tongue ${ }^{2}$ in teaching at the lower primary level. The policy stipulates that the majority of instructional time is spent on L1 (90\% in kindergarten and $80 \%$ in Primary 1) while time for English gradually increases to $50 \%$ by Grade 3. The use of English as a medium of instruction is expected to take effect from Grade 4 (National Literacy Acceleration Programme, ${ }^{3}$ 2009).

Three teaching sessions were observed. The first lesson was in Environmental Science at the Anglican primary school, and the topic was 'dental care'. The topic was mentioned in English and then translated into Akan. The following is an excerpt of the teaching session.

\section{Environmental Science lesson in Primary 1}

Teacher: Everybody let me see your teeth. What are the uses of your teeth?

Pupil 1: Chewing

Den na wode wo se $y \varepsilon$ ?

Pupil 2: mede we nam

I use them for eating meat

Teacher: Are our teeth useful then?

Class (chorus): Yes!

Teacher: Today, we want to learn how we can take good care of our teeth.

Yebesua scnea yebetumi ahwe yen se so yiye.

Teacher: What is the first thing you do in the morning?

Pupil 3: We wash our face, we brush our teeth.

Teacher: What do we use for brushing our teeth?

Pupil 4: Duawa

Stick

Pupil 5: Brush ne pepsodent

and

Teacher: How many times do we have to brush our teeth in a day?

Pupil 6: Two times

Per Linguam 2015 31(1):74-104

http://dx.doi.org/10.5785/31-1-592 
Teacher: Good, well done!

The teacher introduced the topic in English, and translated it into Twi. After the lesson had been introduced in both English and Twi, the pupils answered questions using either Twi or English, whichever they were proficient in. When the questions required one-word answers, the pupils spoke English; otherwise, Twi was used. The teacher was code-switching between English and Akan throughout the teaching session.

The second session which was observed was a Mathematics lesson. Language choice of pupils was quite different, with English language dominating in the answers that pupils gave. The use of English dominated in the answers, because the questions did not demand complete statements. When the teacher had introduced the topic 'simple division', she went ahead to explain the concept in Akan using objects.

\section{Mathematics lesson in Primary 2}

Teacher: Nnipa baanu kye akutu anan a, obiara benya ahe?

When two people share four oranges, how many will each have?

Pupil 1: Two

Teacher: Nnipa baanu ky kwaadu asia nso $\varepsilon$ ?

And when two people share six fingers of bananas?

Pupil 2: Three, three

Teacher: And when three people share nine pencils?

Na nnipa baasa kye pencil akron nso $\varepsilon$ ?

Pupil 3: Three

The third lesson that the researchers observed was in Religious and Moral Education where the teacher taught the 'creation story' from the Holy Bible. The Bible was read in English, after which the teacher narrated the account in Twi. All the questions were asked in Twi, and the responses from pupils were mostly in Twi. After the lesson, there was a memory verse taught in English. Below is an excerpt of the class session.

Religious and Moral Education lesson in Primary 3

Teacher: Den na Onyankopon bo dii kan?

What did God create first?

Pupil 1: Star, nsoroma

Teacher: Nna ahe na sde bos biribiara?

How many days did He use in creating everything?

Pupils 2: Nnansa

Three days

Teacher: Dabi

No

Pupil 3: Six days

Teacher: Good! 
The teacher narrated the story in Twi after reading from the English Holy Bible, because she intimated that biblical English was sometimes difficult to understand. She could not read the Twi bible so she read in English and then explained in Twi. Pupils gave some one-word answers in English, especially where it was a loan word or lexical items which were better known in English. In most of the instances, the answers were in Twi, but the memory verse was taught in English. During school open days and Children's Day in the Presbyterian Church, for instance, it is reported that school children are made to recite English Bible verses to the admiration of unlettered parents. For the parents of these school children, the ability to recite Bible verses in English was evidence of literacy (Akrofi Ansah, forthcoming).

The three preceding teaching scenarios demonstrated the application of the bilingual model of NALAP. Our observations were that, in the first place, the L1 of the pupils, Leteh, was not used. Secondly, the bilingual policy was not strictly adhered to. Finally, although the policy demanded that Akuapem Twi should be used half the time (see Table 2), the teacher herself had difficulties in reading the Holy Bible in Akan.

It must be emphasised that, although the language policy refers to the use of mother tongue, Leteh is not used in any teaching session, because it is not one of the nine government-sponsored languages. Secondly, even if it were, the teachers of Primary 2 and 3 were not Leteh speakers, and so could not have used Leteh. The teachers admitted that the language policy was not always strictly adhered to. They explained that adherence to the policy was dependent on the lesson; for instance, in a Religious and Moral Education lesson, Twi dominated (Table 4) because the Bible which was the main reference book was written in Twi. On the other hand, English dominated in the Environmental Science and Mathematics lessons, because it was more difficult to find Akan equivalents for some of the scientific and mathematical terms. The explanations offered by the teachers pointed to the fact that it is not enough to use Ghanaian languages as languages of instruction, but there is the need to take a further step to have the Basic Primary textbooks written in those government-sponsored languages in order to give some more backing to the policy.

Table 4 summarises the three scenarios of teaching sessions. In each session, the language which predominates is listed first.

Table 4: Patterns of language in Primary 1-3 classroom (Larteh)

\begin{tabular}{|l|l|l|l|l|l|l|}
\hline Domain & Setting & Speaker & Addressee & Subject & Topic & Language \\
\hline Education & School & Teacher & Pupils & $\begin{array}{l}\text { Environmental } \\
\text { Science }\end{array}$ & $\begin{array}{l}\text { Dental } \\
\text { care }\end{array}$ & $\begin{array}{l}\text { English, } \\
\text { Akan }\end{array}$ \\
\hline & & & & Mathematics & $\begin{array}{l}\text { Simple } \\
\text { division }\end{array}$ & $\begin{array}{l}\text { English, } \\
\text { Akan }\end{array}$ \\
\hline & & & & $\begin{array}{l}\text { Religious and } \\
\text { Moral } \\
\text { Education }\end{array}$ & Creation & $\begin{array}{l}\text { Twi, } \\
\text { English }\end{array}$ \\
\hline
\end{tabular}




\section{Language use in basic schools in Winneba}

From the survey, we found out that over $80 \%$ of children in the schools come from an Efutu speaking background and speak Efutu as their first language. According to the teachers, when the children start school (nursery, kindergarten or Primary 1), they speak only Efutu. Children can therefore be described as monolingual in Efutu when they start school; they can barely speak or understand Fante or English. In spite of the linguistic background of children at the start of school, it was reported that Fante or/and English are used as medium of instruction in schools as per the language-in-education policy. This state of affairs is very unfortunate, and detrimental to the academic progress of the children. As Batibo (1997) reiterates:

...the greatest strength children entering school possess is the language that they bring from home, the instrument they have used to communicate with others, especially members of their family and to make sense of their world. This enables children to find continuity between their first learning context, the home, and the school, making it possible for them to identify with teachers in ways that build on relationships they have with caregivers and friends.

In one of the public schools, the head teacher reported that, regarding language of instruction, the school uses English and Fante in accordance with NALAP. She explained that, in her school, the teachers use 50\% Ghanaian language and 50\% English in the lower primary, and 70\% English and $30 \%$ Ghanaian language in the upper primary. This practice is obviously contrary to the expectations of NALAP. The teacher was not able to offer a good explanation for flouting NALAP's instructions.

In the other schools, no specific model such as NALAP was mentioned. However, it was reported that Fante and English are used as media of instruction. In one private school, it was reported that English was the main language of instruction and Fante was used occasionally, for example when pupils found it difficult to understand a lesson.

Regarding the linguistic background of teachers in the schools, an estimation of less than $20 \%$ of Efutu speakers was reported. Other members of teaching staff came from different language groups such as Akan, Ewe and Ga. English was said to be the main language of communication among teachers in the schools. However, teachers who shared a common language other than English sometimes communicated in that language. During staff meetings and other formal meetings, however, English was the main language used for proceedings.

With regard to the language of communication outside the classroom, we observed that in all four schools, English and Fante were the only approved languages. The speaking of Efutu was prohibited at all times in the school compound, and in some schools, pupils were said to be subjected to various forms of punishment if they were found speaking Efutu during school hours. This means that children are prevented from using their mother tongue, Efutu, even during playtime or break hours in school. The enforcement of this prohibition, however, varied in schools. 


\section{CONCLUSION}

The study investigated the fate of two South Guan dialects in the context of Ghana's language policy on education. The current language policy advocates a bilingual approach which would ensure that pupils in basic school would learn to read and write their mother tongue, and then transfer the knowledge to the learning of English. The study has shown that, although the Ghana language-in-education policy suggests mother tongue education, for dialects like Leteh and Efutu which are not government-sponsored languages, they are not used in basic schools, and indeed, in the case of Efutu, its use is even prohibited at school. What policymakers fail to take note of is the fact that not all the mother tongues of pupils are government-sponsored, and that by selecting about $10 \%$ of languages spoken in Ghana, some minority languages are sacrificed. It must be noted that failure to give recognition to all languages at the basic level of education in Ghana amounts to a denial of the linguistic rights of schoolchildren whose mother tongues are considered as minority languages. If indeed the culture of a people is ingrained in their language, and culture is the embodiment of a people's beliefs and knowledge systems, then every language in Ghana needs to be preserved. We propose that every Ghanaian language must be given the needed support for it to thrive and develop.

\section{ENDNOTES}

\footnotetext{
${ }^{1}$ It is possible to use the Akan orthography to write Leteh, because of similarities at phonological and syntactic levels.

${ }^{2}$ In the policy, mother tongue refers to any of the nine government-sponsored languages.

${ }^{3}$ NALAP was formed to address the literacy crisis in primary education in Ghana.
}

\section{REFERENCES}

ABAKAH, EN. 2006. The Efutu vocalic phonology. Paper presented at the Legon-Trondheim Linguistics project colloquium at the University of Ghana, Legon. January 9-13, 2006.

GHANA EDUCATION SERVICE ACT (506). 1995. Acts of Ghana, fourth republic.

AGYEMAN, NA. 2013. Language use in Winneba - some preliminary observations. SOAS Working Papers in Linguistics, 16:259-277.

ANDOH-KUMI, K. 1997. Language policy for primary schools: quo vadimus. Paper presented at the GESA workshop for teachers at the University of Cape coast, Cape coast.

ANDOH-KUMI, K. 1999. Language policy for primary school: quo vadis. In ME Kropp Dakubu (Ed.) Teaching English in Ghana: A Handbook for Teachers. Workshop Papers Presented August, 1997, pp. 107-126.

BATIBO, HM. 1995. Empowerment of the people through language: The case of English vs. Kiswahili as languages of learning and teaching in Tanzania. In Webb, VN (Ed), The LiCCA research and development report, Lesotho conference in Maseru. Pretoria: University of Pretoria. 209-218.

BATIBO, HM. 1997. The fate of minority languages in Botswana. In Smieja, B \& M Tasch (Eds), Human contact through language and linguistics. Frankfurt: Peter Lang. 243-252.

BATIBO, HM. 2004. The role of minority languages in education and development in Africa. In Kriel, M (Ed), The language web. Port Elizabeth: University of Port Elizabeth. 26-33. 
BAMGBOSE, A. 1991. Language and the nation: the language question in Sub-Saharan Africa. Edinburgh: Edinburgh University Press.

BAMGBOSE, A. 1997. Language as a resource: an African perspective. Workshop paper. Pretoria: University of Pretoria.

BAMGBOSE, A. 2002. Language and exclusion: the consequences of language policies in Africa. Münster: 12 LIT Verlag.

BAMGBOSE, A. 2005. Mother-tongue education: Lessons from the Yoruba experience. In B Brock-Utne \& R Kofi Hopson (Eds.), Languages of instruction for African emancipation: focus on postcolonial contexts and considerations. 210-234.

BAMGBOSE, A. 2011. African languages today: the challenges of and prospects for empowerment under globalization. In: Bokamba, EG et al. (Eds), Selected proceedings of the 40th annual conference on African linguistics. Somerville, MA: Cascadilla Proceedings Project. 1-14.

BOAFO, E, DH HATFIELD \& C KEHL. 2002. Sociolinguistic survey of the Awutu-Efutu language area. SIL electronic survey reports 2002-036: 69. Available from http://www.sil.org/silesr/abstract [Accessed: 1 September 2014].

BROKENSHA, DW. 1966. Social change at Larteh, Ghana. Oxford: Clarendon Press.

COLLINSON, GO. 1972. Language and concept development in Ghana. Elementary school children. Unpublished doctoral dissertation. Boston, MA: Harvard University Graduate School of Education.

EASTMAN, CM. 1983. Language planning: an introduction. San Francisco: Chandler and Sharp.

FAFUNWA, AB. 1989. Education in mother tongue: the Ife primary education research project. Ibadan: University Press.

GHANA STATISTICAL SERVICE. 2012. 2010 Ghana population and housing census.

HAGAN, GP. 2000. Divided we stand - a study of social change among the Efutu of coastal Ghana. Trondheim: Department of History, NTNU.

KAPLAN, RB \& RB BALDAUF Jr. 1997. Language planning. From practice to theory. Clevedon: Multilingual Matters.

KEMBO-SURE, J. 2000. Language in education and language learning in Africa. In Webb, VN \& J Kembo-Sure (Eds), African voices: an introduction to the languages of Africa. Cape Town: Oxford University Press.

KROPP-DAKUBU, ME. 1988. The languages of Ghana. London: Kegan Paul.

LEWIS, MP, FS GARY \& CD FENNIG (Eds). 2013. Ethnologue: languages of the world, 17th edition. Dallas, TX: SIL International. Available from http://www.ethnologue.com [Accessed: 1 September 2014]

LEWIS, MP (Ed). 2009. Ethnologue: languages of the world. 16th edition. Dallas, TX: SIL International. Available from http://www.ethnologue.com [Accessed: 1 September 2014]

MINISTRY OF EDUCATION, GHANA. 2003. Education strategic plan 2003-2015. Accra: Ministry of Education.

MINISTRY OF EDUCATION, GHANA. Ghana education reform 2007. Available from http://planipolis.iiep.unesco.org/upload/Ghana/Ghana_education_reform_2007df [Accessed: 1 September 2014]

MINISTRY OF EDUCATION, GHANA. 2008. 2007 National education assessment report. Accra: Ministry of Education. 
MINISTRY OF EDUCATION, GHANA. 2009. National literacy acceleration program (NALAP) baseline assessment. Available from http://pdf.usaid.gov/pdf_docs/PNADW581.pdf [Accessed: 1 September 2014].

OWU-EWIE, C. 2006. The language policy of education in Ghana: A critical look at the Englishonly language policy of education. In Mugane, J et al. (Eds), Selected proceedings of the 35th annual conference on African linguistics. Somerville, MA: Cascadilla Proceedings Project. 76-85.

RIIS, HN. 1854. Grammatical outline and vocabulary of the Oji language. Basel: C Detlof.

SCHWARTZ, M, V MOIN \& M LEIKIN. 2012. Lexical knowledge development in the first and second languages among language-minority children: the role of bilingual versus monolingual pre-school education. International Journal of Bilingual Education and Bilingualism, 15(5):549-571.

UNESCO. 1996. Declaration on linguistic rights. World conference on linguistic rights, Barcelona, Spain, June 9, 1996.

WELMERS, W. 1973. African language structures. University of California Press.

WILLIAMSON, B \& R BLENCH. 2000. Niger-Congo. In Heine, B \& D Nurse (Eds), African languages. An introduction. Cambridge: Cambridge University Press. 11-42.

\section{BIOGRAPHICAL NOTE}

Mercy Akrofi Ansah is a research fellow of the Institute of African Studies, University of Ghana. She did her doctoral studies in Linguistics at the University of Manchester, UK. Her research interests are the following: documenting and describing less-studied languages; language use in multilingual communities; and adult functional literacy. She has a number of publications in these areas in local and international journals. She is a fellow (F'11) of the American Council for Learned Societies. She is a member of the Linguistics Association of Ghana; Association of African Studies of Africa; Association of Contemporary African Linguistics.

Nana Ama Agyeman holds a BA degree in Linguistics and Philosophy from the University of Ghana and an MPhil degree in Linguistics from the Norwegian University of Science and Technology. She is currently working towards the completion of her PhD in Linguistics at SOAS, University of London. Her PhD research is on documentation and description of Efutu language (Niger-Congo, Kwa, Guan), southern Ghana. Her PhD thesis presents a descriptive grammar of Efutu with a focus on serial verb constructions. She has been working at the Language Centre of the University of Ghana since 2003. 